\title{
CYTOGENETICAL EVIDENCE ON THE QUESTION OF AFFINITY IN COTTON*
}

\author{
LYLE L. PHILLIPS \\ Department of Crop Science, North Carolina State College, Raleigh, N.C.
}

Received 27.v.63

\section{INTRODUCTION}

THE preponderance of parental-like phenotypes in $F_{2}$ and $F_{3}$ generations of hybrids involving species with the New World (Gossypium hirsutum L., G. barbadense L. and G. tomentosum Nuttall) and Asiatic (G. arboreum L. and $G$. herbaceum L.) groups of cultivated cotton, has been noted and studied by many geneticists during the last 30 years. Two explanations for this phenomenon have been evolved during this time: (I) the Harland (I933) school explains $F_{2}$ and $\mathbf{F}_{3}$ genetic breakdown on the basis of the disruption of coadapted arrangements of major and modifier genes such that the only recombinants that survive are those with genic architectures most like the parental types. (2) The model of Stephens (1950) attributed the cause of genetic breakdown in $G$. hirsutum $\times$ barbadense and $G$. arboreum $\times$ herbaceum derivatives to minute chromosome structural dissimilarities unique to each species that become translated into cryptic duplications and deficiencies via crossing-over during gametogenesis. As in the Harland model, the gametes and zygotes that survive are those with a minimum of recombined chromatin.

Wallace ( 1960 ) has reviewed portions of the evidence upon which these two theories were based and has concluded that a re-interpretation of these data can be based on the theory of affinity. Affinity is a concept elaborated by Michie (1953) and Wallace (1953), originally based on studies of mouse genetics, which proposes that in material of hybrid origin there is a non-random assortment of chromosomes during meiosis mediated by an affinity among the centromeres contributed to the hybrid by each parent. Affinity could thus account for, or at least be involved in, the preponderance of parental-like phenotypes usually found in $\mathrm{F}_{2}$ and $\mathrm{F}_{3}$ progenies of cotton hybrids.

Tests for determining whether affinity is operative in cotton are of two types: (I) A genetical test of quasi-linkage for markers known to be on different chromosomes. (2) Another test is possible if, as in cotton, there are karyotypic differences among the taxa. Cytological analysis can, in an appropriate $F_{1}$ hybrid, be used as a basis for

\footnotetext{
* Contribution from the Crop Science Department, North Carolina Agricultural Experiment Station, Raleigh, N.C. Published with approval of the Director of Research as Paper No. I60I of the Journal Series and with approval of the Crops Research Division, Agricultural Research Service, U.S.D.A.; supported in part by Project S-I of the Research and Marketing Act of I 946 . Aided by grant G-I 4203 of the National Science Foundation. 
determining whether meiotic disjunction and assortment of the chromosomes is random or preferential. The present study is concerned with each of these tests of the theory of affinity as it applies to cotton.

\section{METHODS AND MATERIALS}

The genetic test for quasi-linkage was accomplished by assessing segregation from a hybrid of $G$. thurberi Tod. and $G$. armourianum Kearney. The hybrid of these two species, which are members of the American group (D genome) of wild diploid cottons, segregates for four phenotypes which are conditioned by simply inherited and unlinked genes. $G$. thurberi contains alleles $y^{T H U}$, cream pollen; $p^{T H U}$ cream corolla; $r^{T H U}$, petal spotless; and $L^{T H U}$, lobed leaf. The contrasting alleles in G. armourianum are $Y^{A R M}$, yellow pollen; $P^{A R M}$, yellow petal; $R^{A R M}$, petal spot; and $l^{A R M}$, entire leaf.

\section{TABLE I}

Genetic segregation for four marker loci in the progeny of G. hirsutum $\times(G$. thurberi $\times$ armourianum)

\begin{tabular}{|c|c|c|c|}
\hline $\begin{array}{c}\text { Allelic } \\
\text { Combination }\end{array}$ & No. Obs. & $\begin{array}{l}\text { No. Exp, } \\
(\mathrm{r}: 4: 6: 4: 1)\end{array}$ & $\chi^{2}$ \\
\hline $\begin{array}{l}4 \text { ARM alleles } \\
\text { o THU alleles . }\end{array}$ & 39 & $34 \cdot 8$ & $0.5^{1}$ \\
\hline $\begin{array}{l}3 \text { ARM alleles . } \\
\text { I THU allele } .\end{array}$ & 130 & $139 \cdot 2$ & $0.6 \mathrm{I}$ \\
\hline $\begin{array}{l}2 \text { ARM alleles. } \\
2 \text { THU alleles . }\end{array}$ & 207 & $208 \cdot 8$ & 0.01 \\
\hline $\begin{array}{l}\text { I ARM allele . } \\
3 \text { THU alleles . }\end{array}$ & 149 & $139 \cdot 2$ & 0.69 \\
\hline $\begin{array}{l}0 \text { ARM alleles . } \\
4 \text { THU alleles } .\end{array}$ & $3^{2}$ & $34 \cdot 8$ & 0.23 \\
\hline Total & 557 & $55^{6 \cdot 8}$ & $2 \cdot 05$ \\
\hline
\end{tabular}

$$
x^{2}=2 \cdot 05, \text { d.f. }=4, P=0.72
$$

The G. thurberi $\times$ armourianum $\mathrm{F}_{1}$ was test-crossed to Coker 1oo, a commercial $G$. hirsutum, which is recessive for these four markers.

The cytological tests were made on each of two hybrids; $G$. sturtii von Muell. $\times$ G. aridum (Rose and Standley) Skovsted and $G$. sturtii $\times$ G. lobatum Gentry. G. sturtii is a member of a wild Australian group ( $\mathrm{C}$ genome) of diploid cottons having the largest metaphase chromosomes of any in the genus, and G. aridum and G. lobatum are wild American diploids (D genome), the group of the genus with the smallest metaphase chromosomes. There is a range in chromosome size within the complement of both the $\mathrm{C}$ and $\mathrm{D}$ species but no difficulty is encountered in distinguishing between the smallest $\mathrm{C}$ chromosomes and the largest $\mathrm{D}$ chromosomes at $\mathrm{MI}$ in either the $G$. sturtii $\times$ aridum or $G$. sturtii $\times$ lobatum hybrids (Plate-fig. I).

Chromosome pairing in each of these hybrids is incomplete; the range in bivalents per cell for $G$. sturtii $\times$ aridum is from 4 to I3 (I3 II possible) with an average of 8.98 II per cell. Bivalent range for $G$. sturtii $\times$ lobatum is from 2 to I I, the average number of bivalents per cell being 5.33 . The C-D chromosome orientation relative to the two poles was scored at MI in each of the hybrids. Though the alignment of both univalents and bivalents was scored, only data on bivalent associations are recorded in tables 2 and 3 . 


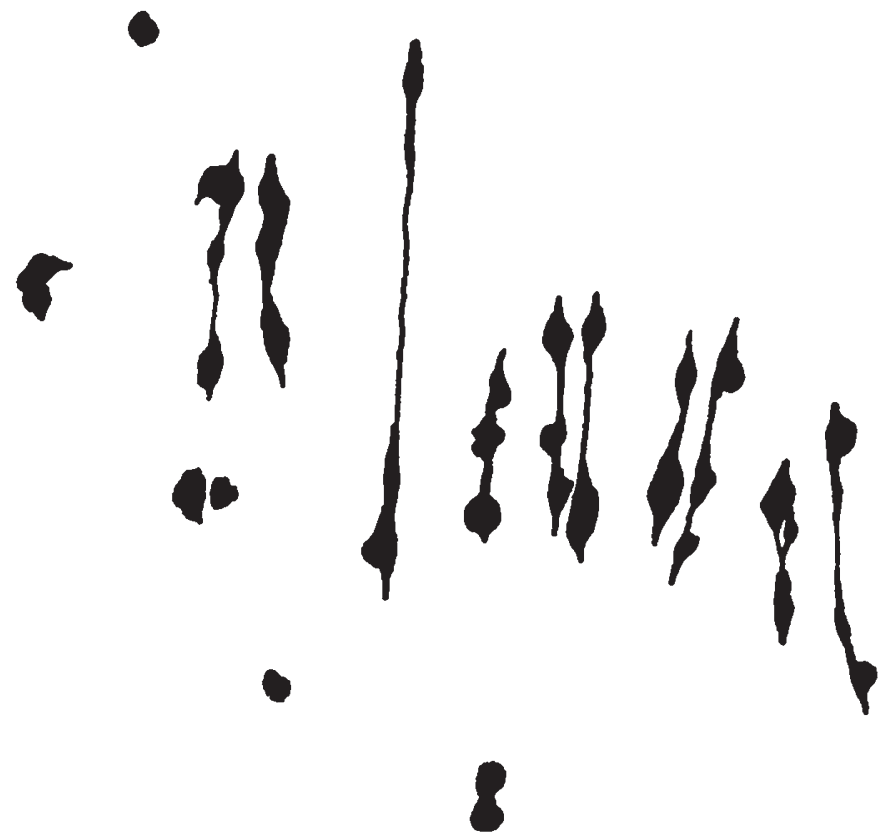

FiG. 1.-Metaphase I cell of $C_{\text {. }}$ sturtii $\times$ aridum showing to heteromorphic C-D bivalents and 6 univalents $\times 3000$.

TABLE 2

Distribution of $\mathrm{G}$. sturtii ( $C$ genome) and $\mathrm{G}$. aridum ( $D$ genome) chromosomes to the poles at Metaphase $I$ in $F_{1} G$. sturtii $\times$ aridum

\begin{tabular}{|c|c|c|c|c|c|c|c|c|c|c|c|c|}
\hline \multirow{2}{*}{$\begin{array}{l}\text { Bivalents } \\
\text { per cell }\end{array}$} & \multirow{2}{*}{$\begin{array}{l}\text { No. of } \\
\text { observations }\end{array}$} & \multirow{2}{*}{\multicolumn{7}{|c|}{ C-D chrom. assort. array (folded) }} & \multicolumn{4}{|c|}{ Goodness of fit } \\
\hline & & & & & & & & & $x^{2}$ & df. & $\mathbf{P}$ & $-2 \ln p^{4}$ \\
\hline 4 & 1 & & $\begin{array}{l}3-1 \\
(1)\end{array}$ & $4-0$ & & & & & & & & \\
\hline 5 & 5 & $\begin{array}{l}3-2 \\
(4)\end{array}$ & $4-1$ & $5 \cdot 0$ & & & & & & & & \\
\hline 6 & 12 & $\begin{array}{l}(4) \\
3-3 \\
(3)\end{array}$ & $\begin{array}{l}4-2 \\
(5)\end{array}$ & $\begin{array}{l}5-I \\
(4)\end{array}$ & $6-0$ & & & & 0.87 & 2 & 0.65 & 0.86 \\
\hline 7 & 13 & $\begin{array}{l}4-3 \\
(6)\end{array}$ & $\begin{array}{l}5-2 \\
5(5)\end{array}$ & $\begin{array}{l}6-1 \\
(1)\end{array}$ & $7-0$ & & & & $0 \cdot 30$ & 1 & 0.60 & 1.02 \\
\hline 8 & 16 & $\begin{array}{l}4-4 \\
(6)\end{array}$ & $\begin{array}{l}5-3 \\
(14)\end{array}$ & $\begin{array}{l}6-2 \\
(9)\end{array}$ & $\begin{array}{l}7-1 \\
(5)\end{array}$ & $\begin{array}{l}8.0 \\
(2)\end{array}$ & & & $9 \cdot 28$ & 3 & 0.03 & $7 \cdot 02$ \\
\hline 9 & 35 & $\begin{array}{l}5-4 \\
\text { (15) }\end{array}$ & $\begin{array}{c}6-3 \\
(15)\end{array}$ & $\begin{array}{c}7-2 \\
(4)\end{array}$ & $\begin{array}{l}8-1 \\
(1)\end{array}$ & $9-0$ & & & $1 \cdot 58$ & 2 & 0.46 & $1 \cdot 56$ \\
\hline 10 & 27 & $\begin{array}{l}5-5 \\
(5)\end{array}$ & $\begin{array}{l}6-4 \\
(13)\end{array}$ & $\begin{array}{l}7-3 \\
(4)\end{array}$ & $\begin{array}{l}8-2 \\
(4)\end{array}$ & $\begin{array}{c}9-1 \\
(1)\end{array}$ & $10-0$ & & $2 \cdot 92$ & 3 & 0.42 & $1 \cdot 74$ \\
\hline II & 20 & $\begin{array}{l}6.5 \\
\text { (10) }\end{array}$ & $\begin{array}{l}7-4 \\
(4)\end{array}$ & $\begin{array}{l}8 \cdot 3 \\
(4)\end{array}$ & $\begin{array}{l}9-2 \\
\text { (2) }\end{array}$ & $10-1$ & $11-0$ & & $1 \cdot 39$ & 2 & 0.50 & $1 \cdot 38$ \\
\hline 12 & 16 & $\begin{array}{l}6-6 \\
(3)\end{array}$ & $\begin{array}{l}7-5 \\
(6)\end{array}$ & $\begin{array}{l}8-4 \\
(6)\end{array}$ & $9-3$ & $\begin{array}{c}10-2 \\
(1)\end{array}$ & $t 1-1$ & $12-0$ & $I \cdot 11$ & 2 & $0.5^{8}$ & 1.08 \\
\hline 13 & $\frac{1}{166}$ & $7-5$ & $\begin{array}{l}8-5 \\
(1)\end{array}$ & $9-4$ & $10 \cdot 3$ & $17-2$ & $12-1$ & $13-0$ & & & & $\overline{14 \cdot 66}$ \\
\hline
\end{tabular}

$-2 \ln \mathrm{P}=14 \cdot 66$, d.f. $=1_{4}, P=0.4{ }^{t}$

* Anderson and Bancroft, 1952. 
Since the G-D chromosome alignment in one pole of any cell is the reciprocal of the other pole, the arrangement for only one pole is recorded in tables 2 and 3 . A further simplification in the presentation of the tabular data was effected by "folding" the assortment array within each bivalent class, i.e., in the 6-bivalent class the ${ }_{4} \mathrm{C}-2 \mathrm{D}$ and ${ }_{2} \mathrm{C}-4 \mathrm{D}$ subclasses are pooled, etc. This also has the effect of increasing the population size of each subclass, thus making a $\chi^{2}$ test more reliable.

To test the hypothesis that chromosome alignment in the two hybrids was random the observed results for each bivalent class were compared with the expanded (and

TABLE 3

Distribution of G. sturtii ( $C$ genome) and G. lobatum ( $D$ genome) chromosomes to the poles at Metaphase $I$ in $F_{1}$ G. sturtii $\times$ lobatum

\begin{tabular}{|c|c|c|c|c|c|c|c|c|c|c|c|}
\hline \multirow{2}{*}{$\begin{array}{l}\text { Bivalents } \\
\text { per cell }\end{array}$} & \multirow{2}{*}{$\begin{array}{l}\text { No. of } \\
\text { observations }\end{array}$} & \multirow{2}{*}{\multicolumn{6}{|c|}{ C-D chrom. assort. array (folded) }} & \multicolumn{4}{|c|}{ Goodness of fit } \\
\hline & & & & & & & & $x^{2}$ & d.f. & $\mathbf{P}$ & $-2 \ln p *$ \\
\hline 2 & 12 & $\begin{array}{l}I-I \\
(8)\end{array}$ & $\begin{array}{l}2-o \\
(4)\end{array}$ & & & & & I·33 & I & $0 \cdot 25$ & $2 \cdot 78$ \\
\hline 3 & 22 & $\begin{array}{l}2-1 \\
(18)\end{array}$ & $\begin{array}{l}3^{* o} \\
(4)\end{array}$ & & & & & 0.55 & I & 0.47 & $I \cdot 52$ \\
\hline 4 & 36 & $\begin{array}{r}2-2 \\
\text { (13) }\end{array}$ & $\begin{array}{l}3-1 \\
(22)\end{array}$ & $\begin{array}{l}4-0 \\
\text { (1) }\end{array}$ & & & & 0.30 & I & $0.6 \mathrm{I}$ & 0.98 \\
\hline 5 & 39 & $\begin{array}{c}3-2 \\
(25)\end{array}$ & $\begin{array}{l}4^{-I} \\
\text { (II) }\end{array}$ & $\begin{array}{l}5^{-0} \\
(3)\end{array}$ & & & & 0.42 & I & 0.51 & I.34 \\
\hline 6 & 39 & $\begin{array}{l}3-3 \\
\text { (14) }\end{array}$ & $\begin{array}{l}4-2 \\
\text { (19) }\end{array}$ & $\begin{array}{l}5-I \\
(5)\end{array}$ & $\begin{array}{l}6-0 \\
\text { (I) }\end{array}$ & & & $1 \cdot 30$ & 2 & 0.55 & $I \cdot 20$ \\
\hline 7 & 23 & $\begin{array}{l}4-3 \\
\text { (16) }\end{array}$ & $\begin{array}{l}5-2 \\
(5)\end{array}$ & $\begin{array}{l}6-I \\
(2)\end{array}$ & $7=0$ & & & $2 \cdot 04$ & I & 0.17 & $3 \cdot 54$ \\
\hline 8 & 25 & $\begin{array}{l}4-4 \\
(5)\end{array}$ & $\begin{array}{r}5-3 \\
\text { (12) }\end{array}$ & $\begin{array}{l}6-2 \\
(6)\end{array}$ & $\begin{array}{l}7-I \\
(2)\end{array}$ & $8-0$ & & 0.67 & 2 & 0.73 & 0.64 \\
\hline 9 & 3 & $\begin{array}{l}5-4 \\
(2)\end{array}$ & $\begin{array}{l}6-3 \\
\text { (I) }\end{array}$ & $7-2$ & $8-I$ & $9=0$ & & & & & \\
\hline 10 & 3 & $\begin{array}{l}5-5 \\
(2)\end{array}$ & $\begin{array}{l}6-4 \\
(1)\end{array}$ & $7-3$ & $8-2$ & $9-I$ & $10=0$ & & & & \\
\hline II & $\frac{I}{203}$ & (I) & $7-4$ & $8-3$ & 9-2 & IO-I & $I I=0$ & & & & $\overline{12 \cdot 00}$ \\
\hline
\end{tabular}

$-2 \ln \mathrm{p}=12 \cdot 00$, d.f. $=14, \mathrm{P}=0.6 \mathrm{r}$.

* Anderson and Bancroft, 1952.

folded) binomial raised to the appropriate power. Due to the paucity of observations in the 4-, 5- and I 3-bivalent classes of G. sturtii $\times$ G. aridum, and the 9-, 10- and I I-pair classes of $G$. sturtii $\times G$. lobatum, these classes were ignored in the $\chi^{2}$ test and two to several subclasses were combined in each of the pairing classes in order to eliminate sub-classes with less than five observations from $\chi^{2}$ computations. The probability values from each bivalent class were combined according to Anderson and Bancroft (1952).

\section{RESULTS}

The segregation of marker genes in the progeny of $G$. thurberi $\times$ armourianum was at random (table I), indicating a complete lack of preferential affinity of the centromeres (or associated chromatin) contributed to the hybrid by its parental species.

The results of the cytological analysis of $G$. sturtii $\times$ aridum and 
G. sturtii $\times$ lobatum also failed to show evidence of centromeric and/or chromosomal affinity. The $\chi^{2}$ probability value for the test of random C-D chromosome alignment at $\mathrm{MI}$ in $G$. sturtii $\times$ aridum was $0.4 \mathrm{I}$ and for $G$. sturtii $\times$ lobatum the probability was $0 \cdot 6 \mathrm{I}$.

\section{DISCUSSION}

Attempts were made to score $\mathrm{F}_{2}$ populations derived from the $G$. thurberi $\times$ armourianum hybrid for pollen colour, corolla colour, petal spot and leaf-shape, but "genetic breakdown" was so severe in the $\mathrm{F}_{2}$ of this cross that such scoring was impossible. A great majority of the $F_{2}$ plants were depauperate, unthrifty individuals which could not be scored at all for flower characteristics and scoring for leaf-shape could not be accomplished with confidence.

This situation, with a preponderance of depauperate individuals among a minority of types resembling one of the parents, indicates that affinity, if operative at all, is unimportant in accounting for the characteristic structure of cotton $\mathrm{F}_{2} \mathrm{~s}$ and $\mathrm{F}_{3} \mathrm{~s}$. Affinity, by definition, is a meiotic phenomenon, and the depauperate individuals in the $F_{2}$ population under discussion, or in the much more intensely studied $\mathrm{F}_{2} \mathrm{~S}$ of $G$. arboreum $\times$ herbaceum and $G$. hirsutum $\times$ barbadense, must be the result of post-meiotic events (gametic and zygotic selection) entirely unrelated to $\mathrm{MI}$ centromeric or chromosomal affinities.

The $G$. hirsutum $\times(G$. thurberi $\times$ armourianum $)$ testcross progeny was uniform and vigorous, and all but three of the plants produced flowers. As indicated above, segregation for four markers was completely at random.

The cell populations from the cytological study were grouped into pairing classes for analysis since it seemed possible that if affinity obtained, it should be more pronounced in the high-bivalent categories due to a "snowballing" effect; i.e., if we view the movement of pachytene bivalents to the metaphase plate as sequential events, and if the first few bivalents in a high-bivalent cell align themselves (by chance) in a non-random manner, then the remaining bivalents could be disposed to align in the same non-random manner. The 8-bivalent class of $G$. sturtii $\times$ aridum hybrid was skewed from expected $(\mathrm{P}=0.03)$, but inasmuch as the 9-, IO-, II- and I2-bivalent classes had normal distributions, there is little basis to ascribe this skewness to affinity.

There was no significant skewness for any of the bivalent classes in G. sturtii $\times$ lobatum. For one class in this hybrid (7-bivalent category) there was a tendency toward skewness $(P=0.17)$ but this was due to an unexpectedly high number of random orientations.

Wallace documented her case for affinity in cotton on $F_{1}$ hybrids of $G$. arboreum $\times$ herbaceum and $G$. hirsutum $\times$ barbadense. It is impossible to determine whether there is a cytological basis for affinity in these hybrids since they do not combine species that are karyologically differentiated. But since the $F_{1}$ hybrids that provide the basis for the 
present study combine more distantly related species than the $G$. arboreum $\times$ herbaceum and $G$. hirsutum $\times$ barbadense hybrids, the genetical and cytological data are more meaningful in assessing the possible role of affinity in cotton than would be similar data from these latter hybrids, even if available. It seems reasonable to assume that centrotypic differentiation should be more strongly developed between distantly related species than between closely related species, and that if affinity is of importance in any cotton hybrid it should be demonstrable in the hybrids of the present study.

\section{SUMMARY}

The possible role of affinity in accounting for the parental-like phenotypes in $\mathrm{F}_{2}$ and $\mathrm{F}_{3}$ generations of some Gossypium interspecific hybrids previously ascribed to the disruption of coadapted gene complexes and crossing-over between structurally differentiated chromosomes, has been investigated.

No evidence of "quasi-linkage" was found among four chromosomally unlinked markers segregating in a $G$. thurberi $\times$ armourianum $\mathrm{F}_{1}$ hybrid.

The cytologically identifiable chromosomes of two wild cotton groups ( $\mathrm{C}$ genome and $\mathrm{D}$ genome) were oriented and disjoined at random at $\mathrm{MI}$ in the $\mathrm{C} \times \mathrm{D}$ hybrids, $G$. sturtii $\times$ aridum and $G$. sturtii $\times$ lobatum.

These genetical and cytological data indicate that affinity is of little or no importance in accounting for the characteristic structure of Gossypium $\mathrm{F}_{2}$ and $\mathrm{F}_{3}$ progenies.

\section{REFERENCES}

ANDERSON, R. L., AND BANCROFT, T. A. 1952. Statistical Theory in Research. McGrawHill Book Co., New York.

harland, s. c. 1933. The genetical conception of the species. Mem. Acad. Sci. USSR. No. 4 (reprinted in Trop. Agr., 11, 51-53).

MrснIE, D. 1953. Affinity: a new genetic phenomenon in the house mouse. Nature, $I 7 I, 26-27$.

STEPHENs, s. c. 1950. The internal mechanism of speciation in Gossypium. Bot. Rev., $16,115^{-1} 49$.

WALLACE, M. E. 1953. Affinity: a new genetic phenomenon in the house mouse. Nature, $171,27-28$.

WAllaCe, M. E. 1960. Possible causes of affinity in cotton. Heredity, 14, 263-274. 